\title{
Characterization of copper-resistant bacteria and bacterial communities from copper-polluted agricultural soils of central Chile
}

\author{
Fabiola Altimira', Carolina Yáñez ${ }^{1,2}$, Guillermo Bravo ${ }^{1}$, Myriam González ${ }^{1}$, Luis A Rojas ${ }^{1}$ and Michael Seeger ${ }^{1 *}$
}

\begin{abstract}
Background: Copper mining has led to Cu pollution in agricultural soils. In this report, the effects of Cu pollution on bacterial communities of agricultural soils from Valparaiso region, central Chile, were studied. Denaturing gradient gel electrophoresis (DGGE) of the $16 \mathrm{~S}$ rRNA genes was used for the characterization of bacterial communities from Cu-polluted and non-polluted soils. Cu-resistant bacterial strains were isolated from Cu-polluted soils and characterized.

Results: DGGE showed a similar high number of bands and banding pattern of the bacterial communities from Cu-polluted and non-polluted soils. The presence of copA genes encoding the multi-copper oxidase that confers Cu-resistance in bacteria was detected by PCR in metagenomic DNA from the three Cu-polluted soils, but not in the non-polluted soil. The number of Cu-tolerant heterotrophic cultivable bacteria was significantly higher in Cu-polluted soils than in the non-polluted soil. Ninety two Cu-resistant bacterial strains were isolated from three Cu-polluted agricultural soils. Five isolated strains showed high resistance to copper (MIC ranged from 3.1 to $4.7 \mathrm{mM}$ ) and also resistance to other heavy metals. $16 \mathrm{~S}$ rRNA gene sequence analyses indicate that these isolates belong to the genera Sphingomonas, Stenotrophomonas and Arthrobacter. The Sphingomonas sp. strains O12, A32 and A55 and Stenotrophomonas sp. C21 possess plasmids containing the Cu-resistance copA genes. Arthrobacter sp. $\mathrm{O} 4$ possesses the copA gene, but plasmids were not detected in this strain. The amino acid sequences of CopA from Sphingomonas isolates (O12, A32 and A55), Stenotrophomonas strain (C21) and Arthrobacter strain (O4) are closely related to CopA from Sphingomonas, Stenotrophomonas and Arthrobacter strains, respectively.

Conclusions: This study suggests that bacterial communities of agricultural soils from central Chile exposed to long-term Cu-pollution have been adapted by acquiring Cu genetic determinants. Five bacterial isolates showed high copper resistance and additional resistance to other heavy metals. Detection of copA gene in plasmids of four Cu-resistant isolates indicates that mobile genetic elements are involved in the spreading of Cu genetic determinants in polluted environments.
\end{abstract}

Keywords: Copper-resistant bacteria, copA gene, Sphingomonas, Stenotrophomonas, Arthrobacter, Bacterial communities

\footnotetext{
* Correspondence: michael.seeger@usm.cl

'Laboratorio de Microbiología Molecular y Biotecnología Ambiental,

Departamento de Química and Center of Nanotechnology and Systems

Biology, Universidad Técnica Federico Santa María, Avenida España 1680,

Valparaíso, Chile

Full list of author information is available at the end of the article
} 


\section{Background}

Copper is widely distributed in nature and it is often found in the Earth's crust. $\mathrm{Cu}$ is an essential trace element for living organism, playing a role in an important number of biological processes [1,2]. The properties of the metallic form of copper, such as its electricity and heat conductivity, resistance to corrosion, malleability and ductility, have been useful for a wide variety of applications. Elevated levels of $\mathrm{Cu}$ from natural and industrial sources have been reported in several $\mathrm{Cu}$ producing countries such as Chile, China, Indonesia, Russia, Zambia, and Australia [3-8]. The mining activities and the use of pesticides to control plant diseases have increased the $\mathrm{Cu}$ levels in agricultural soils. $\mathrm{Cu}$ could bind to soil components (organic matter, clay minerals, $\mathrm{Fe}, \mathrm{Al}$ and $\mathrm{Mn}$ oxides) leading a significant accumulation in the soil surface [9]. Soil bacteria are responsible for diverse ecological processes, such as biochemical cycling of the elements, plant growth, decomposition of organic matter, maintenance of soil structure, detoxification and pest control [10-13]. $\mathrm{Cu}$ accumulation could induce harmful effects on soil bacteria damaging the biological processes and the soil quality $[10,14,15]$.

Culture independent molecular techniques such as DGGE have been used to study microbial communities. DGGE is based on an amplification step with specific primers to amplify a specific gene (for example, a highly variable region of the 16S rRNA gene) and a denaturing gradient polyacrylamide gel electrophoresis. Studies of soil bacterial community by DGGE revealed that heavy metal contamination in agricultural soils close to copper and zinc smelters may provoke changes in the composition of soil bacterial community and a decrease of the bacterial diversity $[11,16]$. However, changes in the soil bacterial community exposed to heavy metal may vary depending of soil properties, heavy metal bioavailability and the indigenous microbial groups in soil [9].

The genes conferring copper resistance in bacteria are often present in plasmids and organized in an operon [17-19]. The copper resistance is encoded by the cop genes $(\operatorname{cop} A, \operatorname{cop} B, \operatorname{cop} C$ and $\operatorname{cop} D)$ in Cupriavidus metallidurans $\mathrm{CH} 34$, Pseudomonas syringae pv. tomato PT23, Xanthomonas axonopodis pv. vesicatoria E3C5 and Pseudomonas aeruginosa PAO1 and by the pco genes $(p c o A, p c o B, p c o C$ and $p c o D)$ in Escherichia coli strain RJ92 [20-24]. The copA gene encoding a multicopper oxidase ( $p c o A$ gene in $E$. coli) is one of the main genetic determinants involved in $\mathrm{Cu}$-resistance in Gramnegative bacteria. It encodes the multi-copper oxidase that oxidase $\mathrm{Cu}(\mathrm{I})$ to the less toxic chemical form of $\mathrm{Cu}$ (II) $[1,25,26]$. A different $\operatorname{cop} A$ gene that encodes a $\mathrm{Cu}$ transporting P-type ATPase involved in $\mathrm{Cu}$ homeostasis has been described in E. coli and other bacteria [17]. The copA gene encoding a multi-copper oxidase is widely present in $\mathrm{Cu}$-resistant bacterial strains and may represent a relevant marker to study the $\mathrm{Cu}$-resistance in bacteria [26]. The aims of this study were to investigate the effect of long-term $\mathrm{Cu}$ pollution on the bacterial community and the characterization of $\mathrm{Cu}$-resistant bacteria from agricultural sites located close to copper smelters from the Aconcagua valley, central Chile.

\section{Methods \\ Chemicals}

The metal salts $\mathrm{CuSO}_{4} \cdot 5 \mathrm{H}_{2} \mathrm{O}, \mathrm{ZnCl}_{2}, \mathrm{~K}_{2} \mathrm{CrO}_{4}$, $\mathrm{NiCl}_{2} \cdot \mathrm{H}_{2} \mathrm{O}, \mathrm{HgCl}_{2}, \mathrm{CoCl}_{2} \cdot 6 \mathrm{H}_{2} \mathrm{O}, \mathrm{CdCl}_{2} \cdot 2 \mathrm{H}_{2} \mathrm{O}$ (analytical grade) were purchased from Merck (Darmstadt, Germany) and used to prepare stock solutions of $\mathrm{Cu}^{2+}, \mathrm{Zn}^{2+}$, $\mathrm{CrO}_{4}^{2-}, \mathrm{Ni}^{2+}, \mathrm{Co}^{2+}, \mathrm{Cd}^{2+}(800 \mathrm{mM})$, and $\mathrm{Hg}^{2+}(150 \mathrm{mM})$. $\mathrm{HNO}_{3}, \mathrm{HClO}_{4}$ and $\mathrm{H}_{2} \mathrm{SO}_{4}$ (Suprapur) and standard Titrisol solution were obtained from Merck (Darmstadt, Germany). Taq DNA polymerase and bovine serum albumin for PCR were obtained from Invitrogen (Carlsbad, CA, USA). Taq DNA polymerase Stoffel fragment was obtained from Applied Biosystems (Darmstadt, Germany). Tryptic soy broth (TSB) and R2A medium were purchased from BD Diagnostic Systems (Heidelberg, Germany). Formamide and ammonium persulfate (APS), $N, N, N^{\prime}, N^{\prime}$-tetramethylethylenediamine (TEMED) were purchased from Sigma-Aldrich (St. Louis, MO, USA) and urea from Bio Rad (Hercules, CA, USA). Acrylamide was obtained from Winkler (Santiago, Chile).

\section{Soil sampling}

Three composite soil samples were collected from four different agricultural sites in Valparaiso region (central Chile). Each composite sample contained 12 bulk soil cores from the surface stratum $(0-10 \mathrm{~cm}$ depth) taken from three sampling points located in an area of $250 \mathrm{~m}^{2}$ per site. The three $\mathrm{Cu}$-polluted sites were located in the neighborhood of an active or an abandoned $\mathrm{Cu}$ smelter in the Aconcagua valley (Figure 1). These soils were sampled from a pasture soil located in North Chagres (longitude 70 $57^{\prime} 29.95^{\prime \prime} \mathrm{W}$ and latitude $32^{\circ} 46^{\prime} 37.42^{\prime \prime} \mathrm{S}$ ), an artichoke plantation soil from South Chagres (longitude $70^{\circ} 57^{\prime} 57.169^{\prime \prime} \mathrm{W}$ and latitude $32^{\circ} 48^{\prime} 30.254^{\prime \prime} \mathrm{S}$ ) located $3.5 \mathrm{~km}$ distant from North Chagres site and an olive plantation soil from Nilhue (longitude $70^{\circ} 54^{\prime} 40.628^{\prime \prime} \mathrm{W}$ and latitude $32^{\circ} 41^{\prime} 44.577^{\prime \prime}$ S) located 10.8 and $13.5 \mathrm{~km}$ distant from North and South Chagres sites, respectively. Soils were sampled on 6 August 2009. These soils had a $\mathrm{Cu}$ content that ranged from 379 to $784 \mathrm{mg} \mathrm{kg}^{-1}$ dry weight soil (d.w.s). The concentrations exceed the standard acceptable level of $40 \mathrm{mg} \mathrm{kg}^{-1}$ for soil by the Québec regulatory authorities (Ministère de l' Environnement du Québec, 1999). A pasture soil from a non-polluted site was sampled from the Casablanca valley, central Chile on 5 August 2010. The non-polluted 


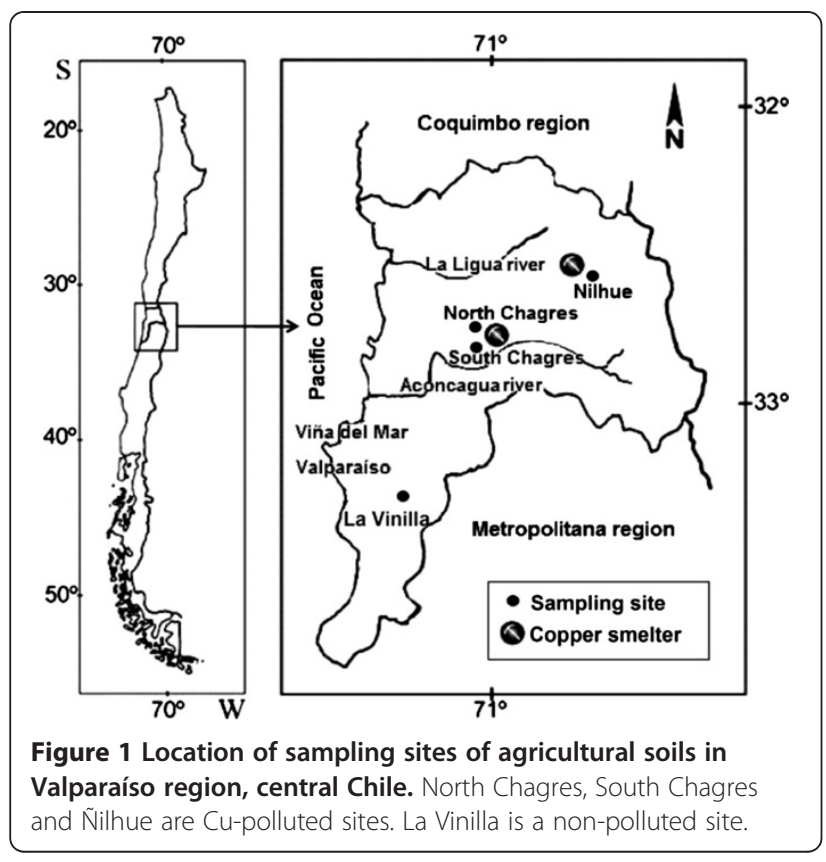

site was located in La Vinilla (longitude $71^{\circ} 24^{\prime} 36^{\prime \prime}$ W and latitude $32^{\circ} 19^{\prime} 30.254^{\prime \prime}$ S) located $62-68 \mathrm{~km}$ distant from the three polluted sites. Soil samples were air-dried and sieved to $2 \mathrm{~mm}$ and homogenized. The soil samples were stored in polyethylene bags and preserved in a dark room at $4^{\circ} \mathrm{C}$ until analyses.

\section{Soil chemical analyses}

Soil $\mathrm{pH}$ was measured using a 1:2 (w/v) a soil/deionized water mixture. The organic matter content was determined by the dichromate oxidation [27]. For heavy metal analyses $(\mathrm{Cu}, \mathrm{Zn}, \mathrm{Pb}, \mathrm{Cr}$ and $\mathrm{Ni}$ ), soils were digested with a 10:4:1 $\mathrm{HNO}_{3} / \mathrm{HClO}_{4} / \mathrm{H}_{2} \mathrm{SO}_{4}$ mixture. Exchangeable $\mathrm{Cu}$ from soils $(1 \mathrm{~g}$ d.w.s $)$ was extracted with $10 \mathrm{ml}$ of $\mathrm{MgCl}_{2}$ solution ( $1 \mathrm{M}, \mathrm{pH}$ 7) at room temperature with continuous agitation for $1 \mathrm{~h}$. Total heavy metal content and the exchangeable $\mathrm{Cu}$ were quantified by atomic absorption spectrometry (AAS) using Spectraa-800 spectrophotometer Varian (Santa Clara, CA, USA).

\section{DNA extraction from soil}

Metagenomic DNA was extracted from $0.5 \mathrm{~g}$ of soil in triplicate using the FastDNA Spin Kit for soil (MP Biomedicals, Solon, Ohio, USA). Cells were disrupted using the FastPrep-24 instrument (MP Biomedicals, Solon, Ohio, USA) following the manufacturer's instructions. Subsequently, the DNA extract was purified by GeneClean Spin Kit (MP Biomedicals, Solon, Ohio, USA). DNA was quantified using Qubit fluorometer (Invitrogen, Carlsbad, CA, USA).

\section{Bacterial community analyses}

Bacterial communities from soils were evaluated using DGGE. The universal primers $27 f$ (5'-AGAGTTT GATCMTGGCTCAG-3') and 1492r (5'-TACGGYTACC TTGTTACGACTT-3') were used for PCR amplification of 16S rRNA genes followed by a nested DGGE-PCR targeting the V6 region of the $16 \mathrm{~S}$ rRNA genes using GC-F968-984 (5'-CGCCCGGGGCGCGCCCCGGGCG GGGCGGGGCACGGGGGGAACGCAAGACCTTAC-3') and R1378-1401 (5'-CGGTGTGTACAAGGCCCGGGAA CG-3') primers [28]. Amplification of $16 \mathrm{~S}$ rRNA gene was conducted in a volume of $25 \mu$ l containing F27 and R1492 primers $(0.6 \mu \mathrm{M})$, deoxyribonucleoside triphosphate (400 $\mu \mathrm{M}$ each), PCR buffer, Taq DNA polymerase (2.5 U), $\mathrm{MgCl}_{2}(3.0 \mathrm{mM})$, bovine serum albumin $\left(0.1 \mathrm{mg} \mathrm{ml}^{-1}\right)$, soil DNA template $(20 \mathrm{ng})$ and ultra pure water. DNA amplification was performed in an Eppendorf Mastercycler thermocycler (Hamburg, Germany) using the following conditions: 1 cycle of $94^{\circ} \mathrm{C}$ for $5 \mathrm{~min}$, and 25 cycles of $94^{\circ} \mathrm{C}$ for $1 \mathrm{~min}, 55^{\circ} \mathrm{C}$ for $1 \mathrm{~min}, 72^{\circ} \mathrm{C}$ for $2 \mathrm{~min}$, plus a final extension at $72^{\circ} \mathrm{C}$ for $10 \mathrm{~min}$. The amplification of $\mathrm{V} 6$ region was conducted using, GC-F968-984 and R1378-1401 primers $(0.6 \mu \mathrm{M})$, deoxyribonucleoside triphosphate $(200 \mu \mathrm{M}$ each), Stoffel buffer, Taq DNA polymerase Stoffel fragment (2.5 U), $\mathrm{MgCl}_{2}(3.0 \mathrm{mM})$, and bovine serum albumin $\left(0.4 \mathrm{mg} \mathrm{ml}^{-1}\right.$ ), $1 \mu \mathrm{l}$ template DNA (obtained from a 1:10 dilution of 16S rRNA amplicon) and ultra pure water. DNA amplification was carried out using the following conditions: 1 cycle of $94^{\circ} \mathrm{C}$ for $5 \mathrm{~min}$, and 20 cycles of $94^{\circ} \mathrm{C}$ for $1 \mathrm{~min}, 55^{\circ} \mathrm{C}$ for $1 \mathrm{~min}, 72^{\circ} \mathrm{C}$ for $1 \mathrm{~min}$, plus a final extension at $72^{\circ} \mathrm{C}$ for $10 \mathrm{~min}$.

DGGE was performed using the method previously reported [28] with minor modifications. The BioRad DCode DGGE system was used with an $8 \%(w / v)$ polyacrylamide gel containing a denaturing gradient from $30 \%$ to $60 \%$ (100\% denaturant contains $40 \%$ (v/v) formamide and $7 \mathrm{M}$ urea). Equal amounts of DNA were loaded on each well. Amplicons were separated at constant voltage of $70 \mathrm{~V}$ for $13 \mathrm{~h}$ at $58^{\circ} \mathrm{C}$. The gel was stained with GelRed (Biotium Inc., Hayward, CA, USA) $1: 10,000(\mathrm{v} / \mathrm{v})$ for $30 \mathrm{~min}$, digitally photographed under UV light and analyzed in a Gel Doc XR System (BioRad, Hercules, CA, USA).

Bands of DGGE profiles were analyzed by using the software Phoretix 1D v11.2 (Non Linear Dynamics, Newcastle, UK). Background noise was subtracted by rolling ball algorithm with a radius of 50 pixels; the automatic band detection was performed with a minimum slope of 100 and a noise reduction of 5 , and peaks smaller than $2 \%$ of the maximum peak were discarded. Bands were manually corrected and matched to create an absent/present binary matrix. A dendrogram was constructed by Unweighted Pair Group Method with Arithmetic Mean (UPGMA), clustering using percentage 
of similarity averages with MultiVariate Statistical Package (MVSP) version $3.13 \mathrm{~h}$ (GeoMem, Blairgowrie, United Kingdom). The diversity of bacterial communities were determined by the Shannon index $\left(H^{\prime}\right)$ that considers the total number of species in a bacterial community ( $S$, richness) and the frequency of the species (abundance). The richness of bacterial community was determined by the number of bands present in DGGE profiles of soils [15]. Three soil replicates were analyzed for each DGGE soil sample.

\section{Detection of copA gene in metagenomic DNA from soils} Metagenomic DNA extracted from each soil was used for $\operatorname{cop} A$ gene amplification. The degenerated primers forward Coprun F2 (5'-GGSASDTACTGGTRBCAC-3') and reverse Coprun R1 (5'-TGNGHCATCATSG TRTCRTT-3') [26] were used for copA gene amplification from soil metagenomic DNA. Degenerated Coprun primers were designed for the amplification of $\operatorname{cop} A$ genes that encode the multi-copper oxidase from Proteobacteria. DNA amplification was performed using the following conditions: 1 cycle of $94^{\circ} \mathrm{C}$ for $3 \mathrm{~min}, 35$ cycles of $94^{\circ} \mathrm{C}$ for $1 \mathrm{~min}, 58^{\circ} \mathrm{C}$ for $1 \mathrm{~min}, 72^{\circ} \mathrm{C}$ for $1 \mathrm{~min}$, plus a final extension at $72^{\circ} \mathrm{C}$ for $7 \mathrm{~min}$.

\section{Enumeration of heterotrophic bacteria and isolation of Cu-tolerant bacteria from soils}

Bacterial cells were extracted from $1 \mathrm{~g}$ of each soil suspended in $9 \mathrm{ml}$ of phosphate buffer $(50 \mathrm{mM}, \mathrm{pH}$ 7) and vigorously shaken in an orbital shaker $(200 \mathrm{rpm})$ for $30 \mathrm{~min}$. After decantation for $1 \mathrm{~min}$, serial dilutions were prepared from the supernatant. The total cultivable heterotrophic bacteria were grown in R2A medium supplemented with cycloheximide $\left(100 \mathrm{mg} \mathrm{l}^{-1}\right)$ [29]. The $\mathrm{Cu}$-tolerant bacteria were grown in same conditions supplemented with $\mathrm{Cu}^{2+}(0.8 \mathrm{mM})$ [30]. Ninety two bacterial strains (29 to 31 from each polluted soil) were isolated based on their capability to grow in presence of $\mathrm{Cu}^{2+}$ $(0.8 \mathrm{mM})$ and the colony morphology. Statistical analysis was performed using one-way ANOVA (OriginPro 8 for Windows). Differences were considered to be significant at $P \leq 0.05$.

\section{Minimum inhibitory concentration (MIC) of $\mathrm{Cu}$ and other heavy metals for bacterial strains}

Bacterial isolates were grown in diluted (1:10) TSB liquid medium. An aliquot $(10 \mu \mathrm{l})$ of each culture grown until stationary phase were placed onto the agar plates with low phosphate Tris mineral salts (LPTMS) medium [31], supplemented with $\mathrm{Cu}^{2+}$ concentrations ranged from 0.8 to $4.7 \mathrm{mM}$ (in increasing concentration of $0.4 \mathrm{mM}$ steps). Inoculated plates were incubated at $30^{\circ} \mathrm{C}$ and checked for growth after $72 \mathrm{~h}$. Experiments were done in duplicate. The lowest heavy metal concentration that prevented growth was recorded as the MIC [31].

The MIC values to $\mathrm{Co}^{2+}, \mathrm{Ni}^{2+}, \mathrm{Zn}^{2+}, \mathrm{Cd}^{2+}, \mathrm{Hg}^{2+}$ and $\mathrm{CrO}_{4}^{2-}$ were studied in bacterial isolates that were capable to grow in presence of $\mathrm{Cu}^{2+}(2.8 \mathrm{mM})$. LPTMS medium supplemented with different concentrations of each heavy metal was used following a protocol previously described [31]. The concentrations of $\mathrm{Co}^{2+}$ ranged from 0.8 to $6.8 \mathrm{mM}$ (in increasing concentration of $0.2 \mathrm{mM}$ steps), $\mathrm{Ni}^{2+}$ ranged from 0.8 to $17 \mathrm{mM}$ (in increasing concentration of $0.3 \mathrm{mM}$ steps), $\mathrm{Zn}^{2+}$ ranged from 0.8 to $17 \mathrm{mM}$ (in increasing concentration of $0.3 \mathrm{mM}$ steps), $\mathrm{Cd}^{2+}$ ranged from 0.4 to $3.6 \mathrm{mM}$ (in increasing concentration of $0.2 \mathrm{mM}$ steps), $\mathrm{Hg}^{2+}$ ranged from 0.005 to $0.5 \mathrm{mM}$ (in increasing concentration of $0.025 \mathrm{mM}$ steps), and $\mathrm{CrO}_{4}^{2-}$ ranged from 0.4 to $8.6 \mathrm{mM}$ (in increasing concentration of $0.2 \mathrm{mM}$ steps). The plates were incubated at $30^{\circ} \mathrm{C}$ for $72 \mathrm{~h}$. The MIC analyses were done in duplicate.

\section{PCR amplification of 16S rRNA and heavy metal resistance genes from bacterial isolates}

PCR reactions were conducted in a volume of $25 \mu \mathrm{l}$ containing specific primers $(0.6 \mu \mathrm{M}$ each), deoxyribonucleoside triphosphate (400 $\mu \mathrm{M}$ each), PCR buffer, Taq polymerase (1.25 U), $\mathrm{MgCl}_{2}(3 \mathrm{mM})$. Genomic DNA was prepared from single colonies re-suspended in $100 \mu \mathrm{l}$ of Tris-EDTA buffer (TE, pH 7.5), heated at $95^{\circ} \mathrm{C}$ for $5 \mathrm{~min}$ and centrifuged briefly. The supernatant $(2 \mu \mathrm{l})$ was used for PCR reactions. The universal primers forward $27 \mathrm{f}$ and reverse $1492 \mathrm{r}$ were used for 16S rRNA gene amplification. The primers forward Coprun F2 and reverse Coprun R1 were used for the amplification of the $\operatorname{cop} A$ gene. The forward primer 5'-GTCGTTAGCTTGCCAACATC-3' and the reverse primer 5'-CGGAAAGCAAGATGTCGAATCG-3' [31] were used for $c h r B$ gene (chromate resistance) amplification. The forward primer 5'-ACCATCGGCGGCA CCTGCGT-3' and the reverse primer 5'-ACCATCG TCAGGTAGGGGAACAA-3' were used for merA gene (inorganic mercury resistance) amplification [32]. The forward primers 5'-TCGCCCATATATTTTAGAAC-3' and the reverse primer 5'-GTCGGGACAGATGCAA AGAAA-3' were used for merB gene (organic mercury resistance) amplification [32]. DNA amplification of $\operatorname{chr}$, merA and merB was carried out using the following conditions: 1 cycle of $94^{\circ} \mathrm{C}$ for $3 \mathrm{~min}$, 30 cycles of $94^{\circ} \mathrm{C}$ for $1 \mathrm{~min}, 57^{\circ} \mathrm{C}$ for $1 \mathrm{~min}, 72^{\circ} \mathrm{C}$ for $1 \mathrm{~min}$, plus a final extension at $72^{\circ} \mathrm{C}$ for $7 \mathrm{~min}$. C. metallidurans MSR33 was used as positive control for $\operatorname{cop} A$, chrB, merA and merB genes [31]. PCR products were visualized by agarose gel electrophoresis followed by staining with GelRed (1:10,000 v/v). 


\section{S rRNA and copA genes sequence analyses}

The PCR products were visualized by agarose gel electrophoresis. Bands were cut from the gel with a scalpel and DNA was recovery using Zimoclean Gel DNA Recovery Kit (Irvine, CA, USA). The purified DNA was sequenced directly by an Applied Biosystem 3730XL DNA sequence (Carlsbad, CA, USA), using the primers 27f and 1492r for 16S rRNA gene and Coprun F2 and Coprun R1 for copA gene sequencing, respectively. The nucleotide sequences of $16 \mathrm{~S}$ rRNA genes were aligned with sequences available in the GenBank (http://www. ncbi.nlm.nih.gov/). The nucleotide sequence of $\operatorname{cop} A$ gene was translated into a protein sequence using blastx. Then, partial sequences of CopA were aligned with other CopA sequences from $\mathrm{Cu}$-resistant bacteria [18]. A phylogenetic analysis was performed to study the evolutionary relationships of the sequences based on the alignments calculated by CLUSTAL W using the default options. The evolutionary history was inferred using the Neighbor-Joining method. Evolutionary analyses were conducted in MEGA 5.05 software [33]. The 16S rRNA gene sequence of strains O12, A32, A55, C21 and O4 were submitted to the EMBL Nucleotide Sequence Database under accession number EMBL:HE608567, EMBL:HE608568, EMBL:HE608569, EMBL:HE608570 and EMBL:HE608571, respectively. The $\operatorname{cop} A$ gene sequence of strains O12, A32, A55, C21 and O4 were submitted to the EMBL Nucleotide Sequence Database under accession number EMBL: HE716432, EMBL:HE716433, EMBL:HE16434, EMBL: HE16435, EMBL:HE16436, respectively.

\section{Plasmid isolation from bacterial strains}

Plasmid isolation from bacterial strains was performed using the method of Kado and Liu [34] with minor modifications [31]. Plasmids were visualized in agarose gel electrophoresis. Bands were cut from the gel with a scalpel and plasmids were recovery from the gel using Zimoclean Gel DNA Recovery Kit (Irvine, CA, USA). The presence of $\operatorname{cop} A$ gene in plasmids was assessed by PCR using the protocol described above.

\section{Results}

The bacterial communities of three Cu-polluted agricultural soils and one non-polluted soil from Valparaíso region, central Chile, were characterized. The three polluted agricultural sites from Aconcagua valley are located close to an active or an abandoned $\mathrm{Cu}$ smelter. An agricultural soil located far away from mining activities in Casablanca valley was selected as a non-polluted site. Soils from Aconcagua valley (loam) and from Casablanca valley (sandy loam) were neutral. Soils from South Chagres and Nilhue showed higher organic matter content (4.5\%) than soils from North Chagres and La
Vinilla (2.3\%). The total $\mathrm{Cu}$ concentrations of the Aconcagua valley soils ranged from 379 to $784 \mathrm{mg} \mathrm{kg}^{-1}$, whereas the total $\mathrm{Cu}$ concentration in the La Vinilla soil was only $21 \mathrm{mg} \mathrm{kg}^{-1}$. The exchangeable $\mathrm{Cu}$ concentration of the North and South Chagres soils was 2.0 and $1.9 \mathrm{mg} \mathrm{kg}^{-1}$, respectively, and $1.2 \mathrm{mg} \mathrm{kg}^{-1}$ for the Nilhue soil. The exchangeable $\mathrm{Cu}$ concentration observed in the La Vinilla soil was below the detection limit $(0.1 \mathrm{mg}$ $\mathrm{kg}^{-1}$ ). The total concentrations of $\mathrm{Zn}$ (ranged from 97 to $205 \mathrm{mg} \mathrm{kg}^{-1}$ ), $\mathrm{Pb}$ (ranged from 33 to $73 \mathrm{mg} \mathrm{kg}^{-1}$ ) and $\mathrm{Cr}$ (ranged from 13 to $19 \mathrm{mg} \mathrm{kg}^{-1}$ ) in $\mathrm{Cu}$-polluted soils from Aconcagua valley were high, whereas in La Vinilla soil heavy metals were present at low concentration.

\section{Bacterial community profiling in agricultural soils by DGGE}

DGGE from the four soils showed complex profiles suggesting a high diversity of the bacterial community in $\mathrm{Cu}$-polluted and non-polluted soils (Figure 2A). UPGMA analysis of banding patterns from bacterial DGGE profiles of the four agricultural sites were grouped into four clusters (Figure 2B). Replicates from each agricultural soil showed a very high similarity (approximately 95\%). Soils from South Chagres, Nilhue and North Chagres showed a high similarity (approximately $80 \%$ ). The non-polluted La Vinilla soil showed a similarity of $73 \%$ with the $\mathrm{Cu}$-polluted soils (Figure $2 \mathrm{~B}$ ). The values of Shannon index obtained for each soil were $3.65 \pm 0.01$ for North Chagres, $3.77 \pm 0.01$ for South Chagres, $3.65 \pm 0.01$ for Nilhue and $3.71 \pm 0.03$ for La Vinilla. The richness values $(S)$ obtained for each soil were $38.67 \pm 0.58$ for North Chagres, $43.67 \pm 0.58$ for South Chagres, $38.33 \pm 0.58$ for Nilhue and $40.67 \pm 1.15$ for La Vinilla (Figure 2B).

\section{PCR detection of Cu-resistance genes in metagenomic DNA from agricultural soils}

The presence of the $\operatorname{cop} A$ gene in the metagenomic DNA from the four agricultural soils was studied. The copA gene was detected by PCR in the three $\mathrm{Cu}$ polluted soils from Aconcagua valley (data not shown). In contrast, the $\operatorname{cop} A$ gene was not detected in the nonpolluted soil from Casablanca valley.

\section{Copper tolerance of bacterial community}

The Cu-tolerance of the bacterial community of the agricultural soils was determined. The cultivable heterotrophic bacteria ranged from $1.2 \times 10^{7}$ to $2.2 \times 10^{7} \mathrm{CFU} \mathrm{g}^{-1}$ d.w.s in $\mathrm{Cu}$-polluted and non-polluted soils. The Cu-tolerant cultivable bacteria ranged from 3 to $23 \%$ (from $7.4 \times 10^{5}$ to $2.8 \times 10^{6} \mathrm{CFU} \mathrm{g}^{-1}$ d.w.s) of the total cultivable heterotrophic bacteria in $\mathrm{Cu}$-polluted agricultural soils from Aconcagua valley. In the non-polluted soil from La Vinilla, the $\mathrm{Cu}$-tolerant bacteria were $0.4 \%\left(5.9 \times 10^{4} \mathrm{CFU} \mathrm{g}^{-1}\right.$ d.w.s $)$. 


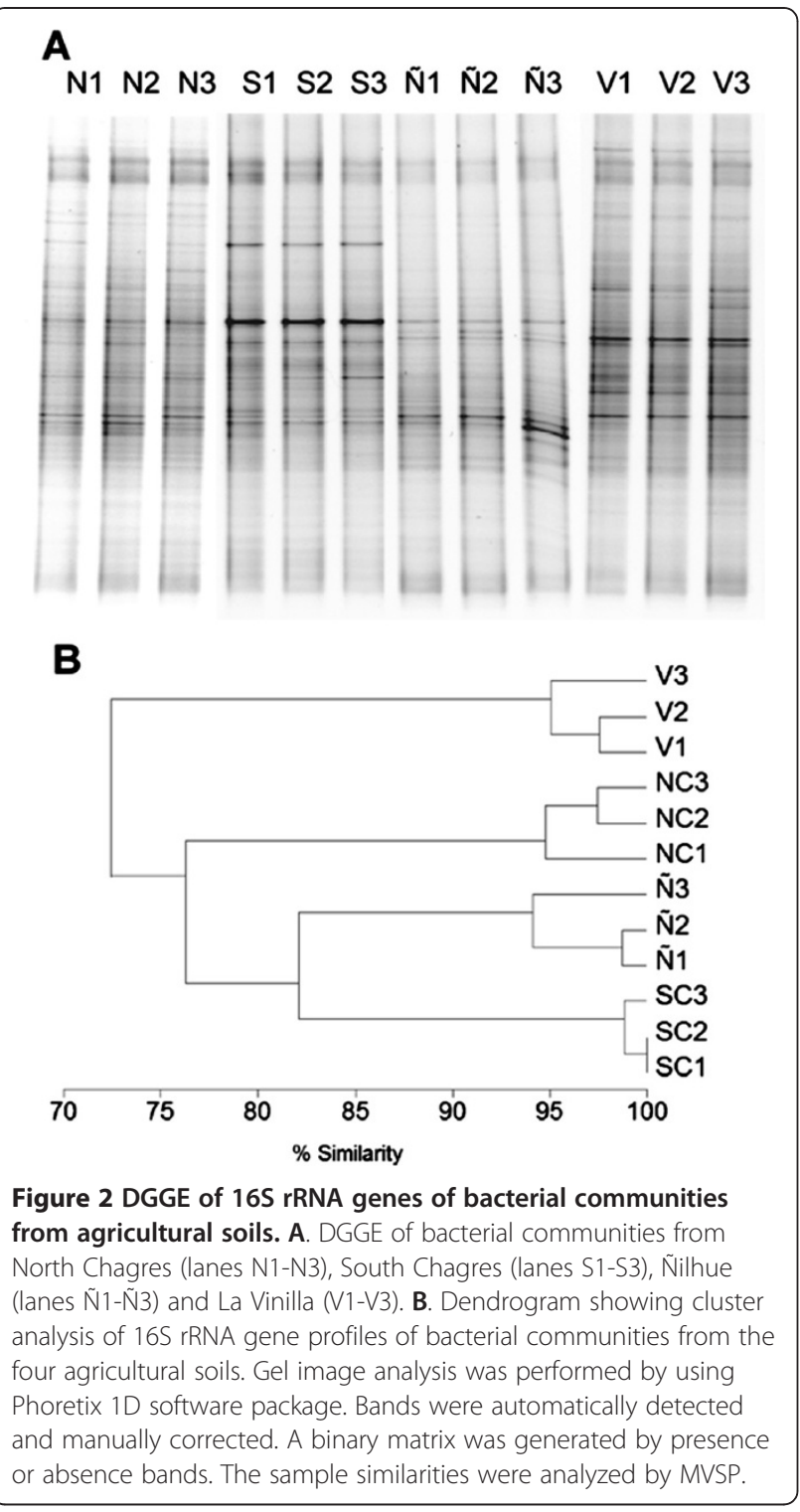

The number of $\mathrm{Cu}$-tolerant cultivable bacteria was significantly larger in $\mathrm{Cu}$-polluted soils than in non-polluted soil $(P \leq 0.05)$. The highest frequency of $\mathrm{Cu}$-tolerant bacteria was found in the $\mathrm{Cu}$-polluted soil of South Chagres, which is the soil with the highest $\mathrm{Cu}$ content, while the lowest rate was found in the non-polluted soil from La Vinilla. These results revealed that $\mathrm{Cu}$-tolerant cultivable bacteria in $\mathrm{Cu}$ polluted soils were approximately 13 to 46 fold higher than in the non-polluted soil (Table 1).

\section{Characterization of Cu-resistant bacterial isolates}

$\mathrm{Cu}$-resistant bacteria were isolated from the three $\mathrm{Cu}$ polluted soils from the Aconcagua valley. A representative collection of 92 bacterial strains (29 to 31 from each $\mathrm{Cu}$-polluted soil) were isolated by enrichment in R2A medium containing $\mathrm{Cu}^{2+}(0.8 \mathrm{mM})$. The soil bacteria
Table 1 Number of heterotrophic and copper-tolerant cultivable bacteria of the agricultural soils

\begin{tabular}{|c|c|c|c|}
\hline \multirow[t]{2}{*}{ Site } & \multicolumn{2}{|c|}{ Log CFU g $^{-1}$ dry weight soil ${ }^{a}$} & \multirow{2}{*}{$\frac{\text { Cu-tolerant/total CFU }}{(\%)}$} \\
\hline & Total & Cu-tolerant & \\
\hline North Chagres & $7.34(0.04)$ & $5.87(0.04)$ & 3 \\
\hline South Chagres & $7.07(0.05)$ & $6.43(0.15)$ & 23 \\
\hline Nilhue & $7.23(0.01)$ & $6.34(0.20)$ & 14 \\
\hline La Vinilla & $7.14(0.03)$ & $4.77(0.05)$ & 0.4 \\
\hline
\end{tabular}

a Standard deviations are indicated in parentheses.

isolated were challenged with successive $\mathrm{Cu}^{2+}$ concentrations from 0.8 to $4.7 \mathrm{mM}$ in LPTMS medium. A marked decrease in the cells number was observed in the medium containing $\mathrm{Cu}^{2+}(2.8 \mathrm{mM})$. Eleven bacteria that were capable of growing in the presence of $\mathrm{Cu}^{2+}$ (2.8 $\mathrm{mM})$ were selected from the 92 isolates for further studies. Two bacterial strains isolated from Nilhue were capable of tolerate $3.5 \mathrm{mM}$ of $\mathrm{Cu}^{2+}$. Three isolates from South Chagres tolerate $3.5 \mathrm{mM}$ of $\mathrm{Cu}^{2+}$. Six strains from North Chagres were capable of tolerate $2.8 \mathrm{mM}$ of $\mathrm{Cu}^{2+}$. The Cu-resistant isolates were challenged to heavy metals for the determination of the MIC values. Five of the eleven $\mathrm{Cu}$-resistant strains isolated (strain C21 from North Chagres, strains A32 and A55 from South Chagres; strains $\mathrm{O} 4$ and $\mathrm{O} 12$ from Nilhue) showed also tolerance to $\mathrm{Co}^{2+}, \mathrm{Ni}^{2+}, \mathrm{Zn}^{2+}, \mathrm{Hg}^{2+}$ and $\mathrm{CrO}_{4}^{2-}$ (Table 2). These five broad-range heavy metal resistant bacteria should possess diverse mechanisms for heavy metal resistance. Therefore, these isolates were selected for further characterization. Strains that were capable to grow in presence of $0.5 \mathrm{mM}$ of $\mathrm{Cu}^{2+}, \mathrm{Co}^{2+}, \mathrm{Ni}^{2+}, \mathrm{Zn}^{2+}$ or $\mathrm{CrO}_{4}^{2-}$ and $0.05 \mathrm{mM}$ of $\mathrm{Hg}^{2+}$ were recorded as tolerant. Strain $\mathrm{O} 12$ showed a high $\mathrm{MIC}$ to $\mathrm{Cu}^{2+}(4.7 \mathrm{mM}), \mathrm{Co}^{2+}$ (2.5 mM), $\mathrm{Ni}^{2+}(17 \mathrm{mM}), \mathrm{Zn}^{2+}(8.5 \mathrm{mM})$ and $\mathrm{Hg}^{2+}$ (0.4 mM). Strain A32 and A55 showed a high MIC to $\mathrm{Cu}^{2+}(3.9 \mathrm{mM}), \mathrm{Co}^{2+}(2.5 \mathrm{mM}), \mathrm{Ni}^{2+}(17 \mathrm{mM}), \mathrm{Zn}^{2+}$ (8.5 mM) and $\mathrm{Hg}^{2+}(0.4 \mathrm{mM})$. Strain O4 showed a high $\mathrm{MIC}$ to $\mathrm{Cu}^{2+}(3.9 \mathrm{mM}), \mathrm{CrO}_{4}^{2-}(4.3 \mathrm{mM}), \mathrm{Co}^{2+}$ (2.5 mM), and $\mathrm{Ni}^{2+}(8.5 \mathrm{mM})$. Strain $\mathrm{C} 21$ showed a high

Table 2 Minimum inhibitory concentration of heavy metal for soil bacterial isolates

\begin{tabular}{lccccccc}
\hline Strain & \multicolumn{7}{c}{$\mathbf{M I C}(\mathbf{m M})$} \\
\cline { 2 - 9 } & $\mathbf{C u}^{2+}$ & $\mathbf{C o}^{2+}$ & $\mathbf{N i}^{2+}$ & $\mathbf{Z n}^{2+}$ & $\mathbf{C d}^{2+}$ & $\mathbf{H g}^{2+}$ & $\mathbf{C r O}_{4}^{2-}$ \\
\hline O12 & 4.7 & 2.5 & 17 & 8.5 & $<0.4$ & 0.4 & $<0.4$ \\
A32 & 3.9 & 2.5 & 17 & 8.5 & $<0.4$ & 0.4 & $<0.4$ \\
A55 & 3.9 & 2.5 & 17 & 8.5 & $<0.4$ & 0.4 & $<0.4$ \\
C21 & 3.1 & 0.8 & 0.9 & $<0.8$ & $<0.4$ & 0.1 & 4.3 \\
O4 & 3.9 & 2.5 & 8.5 & $<0.8$ & $<0.4$ & 0.1 & 4.3 \\
C. metallidurans MSR33 & 3.8 & 20 & 6 & 17 & 2.5 & 0.1 & 0.7
\end{tabular}

${ }^{\text {a Rojas et al. [31]. }}$ 
$\mathrm{MIC}$ to $\mathrm{Cu}^{2+}(3.1 \mathrm{mM}), \mathrm{CrO}_{4}^{2-}(4.3 \mathrm{mM})$ and $\mathrm{Co}^{2+}$ $(0.8 \mathrm{mM})$. All the strains had a low MIC to $\mathrm{Cd}^{2+}$ (lower than $0.4 \mathrm{mM}$ ), indicating that these strains were not resistant to this heavy metal.

\section{Identification of Cu-resistant isolates}

For bacterial identification, comparative $16 \mathrm{~S}$ rRNA gene sequence analyses of the bacterial isolates were used. The results indicated that isolates O12, A32 and A55 belong to the Sphingomonas genus, showing a high $16 \mathrm{~S}$ rRNA gene sequence similarity (98\%) to Sphingomonas paucimobilis. Isolate C21 was identified as a Stenotrophomonas strain, showing a high $16 \mathrm{~S}$ rRNA gene sequence similarity (98\%) to Stenotrophomonas maltophilia. Isolate O4 was identified as an Arthrobacter strain, with high $16 \mathrm{~S}$ rRNA gene sequence similarity (99\%) to Arthrobacter oxydans. The 16S rRNA gene sequences of the isolates and other bacteria including strains from Stenotrophomonas, Sphingomonas and Arthrobacter genera were used to build a phylogenetic tree (Figure 3). Strains O12, A32 and A55 are closely related to Sphingomonas paucimobilis strain OS-64.a. Strain C21 is closely related with Stenotrophomonas maltophilia strains HR69 and d109. Strain O4 is closely related with the Gram-positive bacteria Arthrobacter oxydans WA4-3 and Arthrobacter oxydans EA6-10 (Figure 3).

\section{PCR detection of heavy metal determinants in genomic DNA from bacterial isolates}

The presence of the $\operatorname{cop} A$ gene encoding a multi-copper oxidase in the bacterial isolates was studied by PCR using the Coprun primers. The bacterial strains O12, A32, A55, $\mathrm{C} 21$ and $\mathrm{O} 4$ possess the $\operatorname{cop} A$ genes. The PCR products varied between 1000-1200 bp. The CopA protein sequences were aligned with CopA sequences belonging to $\mathrm{Cu}$-resistant bacteria and were used to construct a phylogenetic tree (Figure 4). Sequence analyses indicate that the copA genes of the isolates encode multi-copper oxidases that are involved in $\mathrm{Cu}$ resistance but that are not associated to degradation of phenolic compounds or polymers. The CopA protein of Sphingomonas sp. strains O12, A32 and A55 are closely related to CopA of other $\alpha$-Proteobacteria, sharing high similarity (93\%) with CopA from Sphingomonas sp. S17. The CopA from Stenotrophomonas sp. strain C21 belongs to the Stenotrophomonas and Xanthomonas CopA branch of the $\gamma$-Proteobacteria and is closely related to CopA from Stenotrophomonas maltophilia R5513 (67\% similarity). The CopA of strain Arthrobacter sp. O4 is closely related to the CopA of Actinobacteria and possess a 68\% similarity with CopA from Arthrobacter sp. strain FB24.

Other heavy metal determinants were studied by PCR using specific primers for $\operatorname{mer} A\left(\mathrm{Hg}^{2+}\right.$ resistance), merB (organomercurial resistance) and $\operatorname{chrB}\left(\mathrm{CrO}_{4}^{2-}\right.$ resistance) genes based on $C$. metallidurans $\mathrm{CH} 34$ sequences. Using these specific primers, the mer $A$, merB and $\operatorname{chr} B$ genes were not detected in the five $\mathrm{Cu}$-resistant bacterial strains.

\section{Detection of plasmids in bacterial isolates}

Sphingomonas sp. strain O12, Sphingomonas sp. strain A32, Sphingomonas sp. strain A55 and Stenotrophomonas sp. strain C21 possessed plasmids (Figure 5). Plasmids were no detected in Arthrobacter sp. strain O4. The plasmids of these four bacterial isolates contained the $\operatorname{cop} A$ gene encoding a multi-copper oxidase (Figure 5).

\section{Discussion}

In this report, the bacterial communities in long-term $\mathrm{Cu}$-polluted agricultural soils from Aconcagua valley, central Chile, were studied and compared with the bacterial community of a non-polluted agricultural soil. The bacterial DGGE profiles showed high similarity (approximately 80\%) among $\mathrm{Cu}$-contaminated soils suggesting a low variation in the dominant bacterial groups in these soils. A similar number of bands and banding pattern was observed by DGGE fingerprints in polluted and non-polluted soils. Despite of the difference in the $\mathrm{Cu}$ content in soils, DGGE studies presented a similar Shannon diversity index $\left(H^{\prime}\right)$ and richness suggesting that the presence of high copper concentration and differences in other soil properties did not affect the diversity of the dominant groups of the bacterial communities detected by DGGE. These results are in agreement with a previous report of soils from abandoned $\mathrm{Cu}$ mines from South Australia that show a low impact of $\mathrm{Cu}$ on the dominant microbial diversity [35]. Probably, bacterial communities from long-term $\mathrm{Cu}$-polluted soils are well adapted to the high $\mathrm{Cu}$ content. Short-term $\mathrm{Cu}$ pollution in soil induces significant modifications in bacterial community structure, but these changes were resilient after a few weeks or months [9]. Our results are in agreement with previous studies showing that $\mathrm{Cu}, \mathrm{Pb}$ and $\mathrm{Zn}$ did not change significantly the bacterial diversity after long-term contamination [36,37].

The $\operatorname{cop} A$ gene that encodes for the multi-copper oxidase is one of the main genetic determinants involved in $\mathrm{Cu}$-resistance $[1,25,26]$. In this report, the presence of $\operatorname{cop} A$ gene was studied in metagenomic DNA from agricultural soils. The $\operatorname{cop} A$ gene was detected in the three $\mathrm{Cu}$-polluted soils. In contrast, the $\operatorname{cop} A$ gene was not detected in metagenomic DNA from soils with low $\mathrm{Cu}$ content. The number of heterotrophic cultivable bacteria was constant in all agricultural soils, whereas, the number of $\mathrm{Cu}$-resistant heterotrophic bacteria was significantly higher in $\mathrm{Cu}$-polluted soils than in the non- 


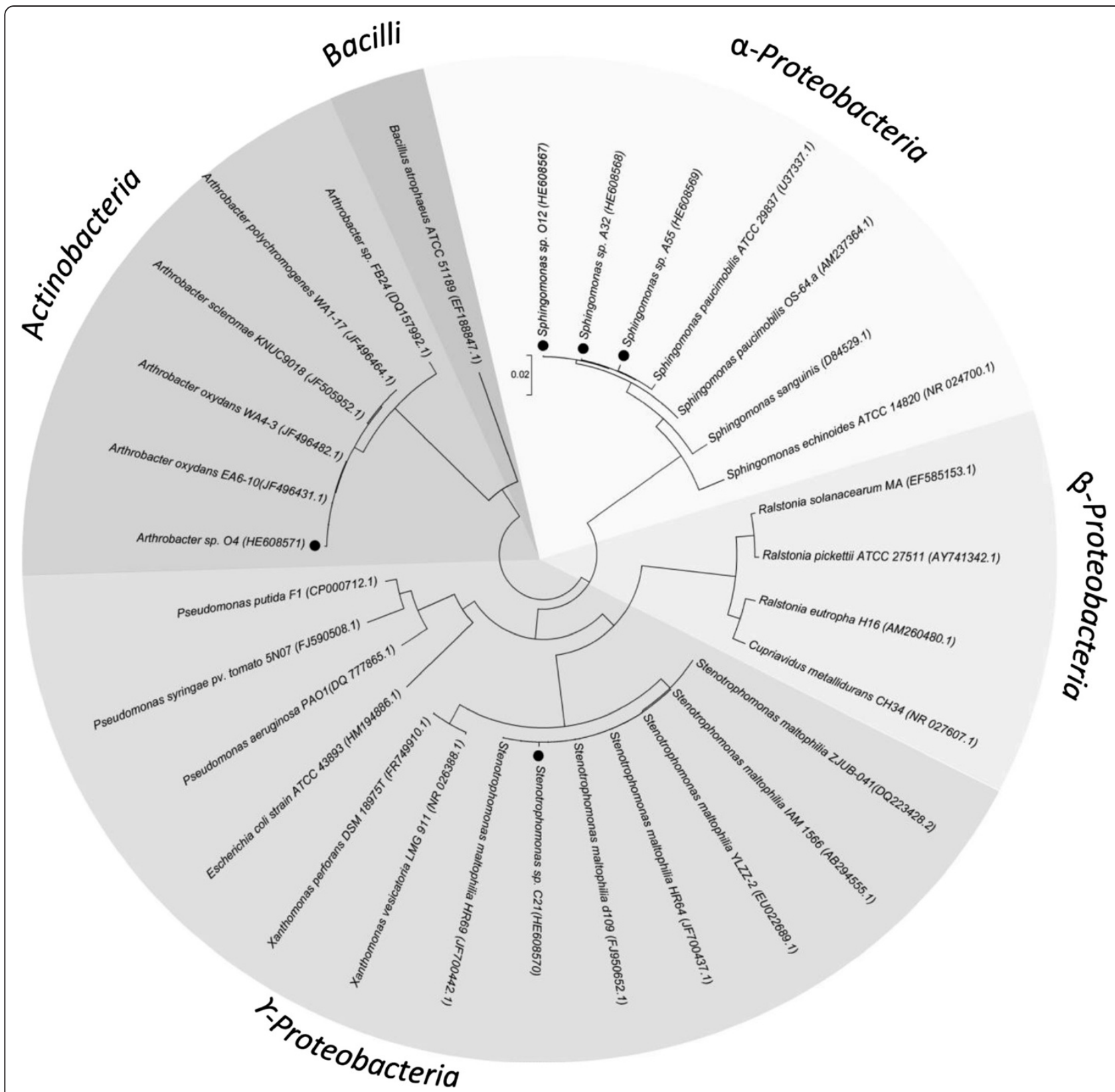

Figure 3 Identification of bacterial isolates by $16 \mathrm{~S}$ rRNA gene sequence analysis. The phylogenetic tree was constructed using neighbor-joining method. Values of 1000 bootstrap replicates above $60 \%$ are given at the branching point. Sequences of the bacterial isolates Sphingomonas sp. strain O12, Sphingomonas sp. strain A32, Sphingomonas sp. strain A55, Stenotrophomonas sp. strain C21 and Arthrobacter sp. strain $\mathrm{O} 4$ are highlighted (black circles). Vertical bar represents 0.02 units of evolutionary distance.

polluted soil. These results suggest that the presence of high levels of $\mathrm{Cu}$ in Aconcagua valley soils is exerting a selective pressure on the bacterial communities, which favors the selection of $\mathrm{Cu}$-tolerant bacteria.

$\mathrm{Cu}$-tolerant bacteria were isolated from the $\mathrm{Cu}$ polluted agricultural soils. Most of bacterial isolates were not capable to grow in LPTMS medium supplemented with $\mathrm{Cu}^{2+}(2 \mathrm{mM})$. Our results are consistent with a previous study that indicates that the number of resistant bacteria decreased at higher $\mathrm{Cu}^{2+}$ concentration [38]. Five isolates, Sphingomonas sp. strain O12, Sphingomonas sp. strain A32, Sphingomonas sp. strain A55, Stenotrophomonas sp. strain C21 and Arthrobacter sp. strain $\mathrm{O} 4$, were resistant to high $\mathrm{Cu}^{2+}$ concentration $(\geq 2.8 \mathrm{mM})$ and other heavy metals. Bacteria that tolerate $\mathrm{Cu}$ concentrations higher than $2 \mathrm{mM}$ should possess an effective resistance system for $\mathrm{Cu}$ detoxification. The isolates Sphingomonas sp. strain O12, Sphingomonas sp. strain A32 and Sphingomonas sp. strain A55, showed a high MIC to $\mathrm{Cu}^{2+}$ (ranged from 3.9 to 


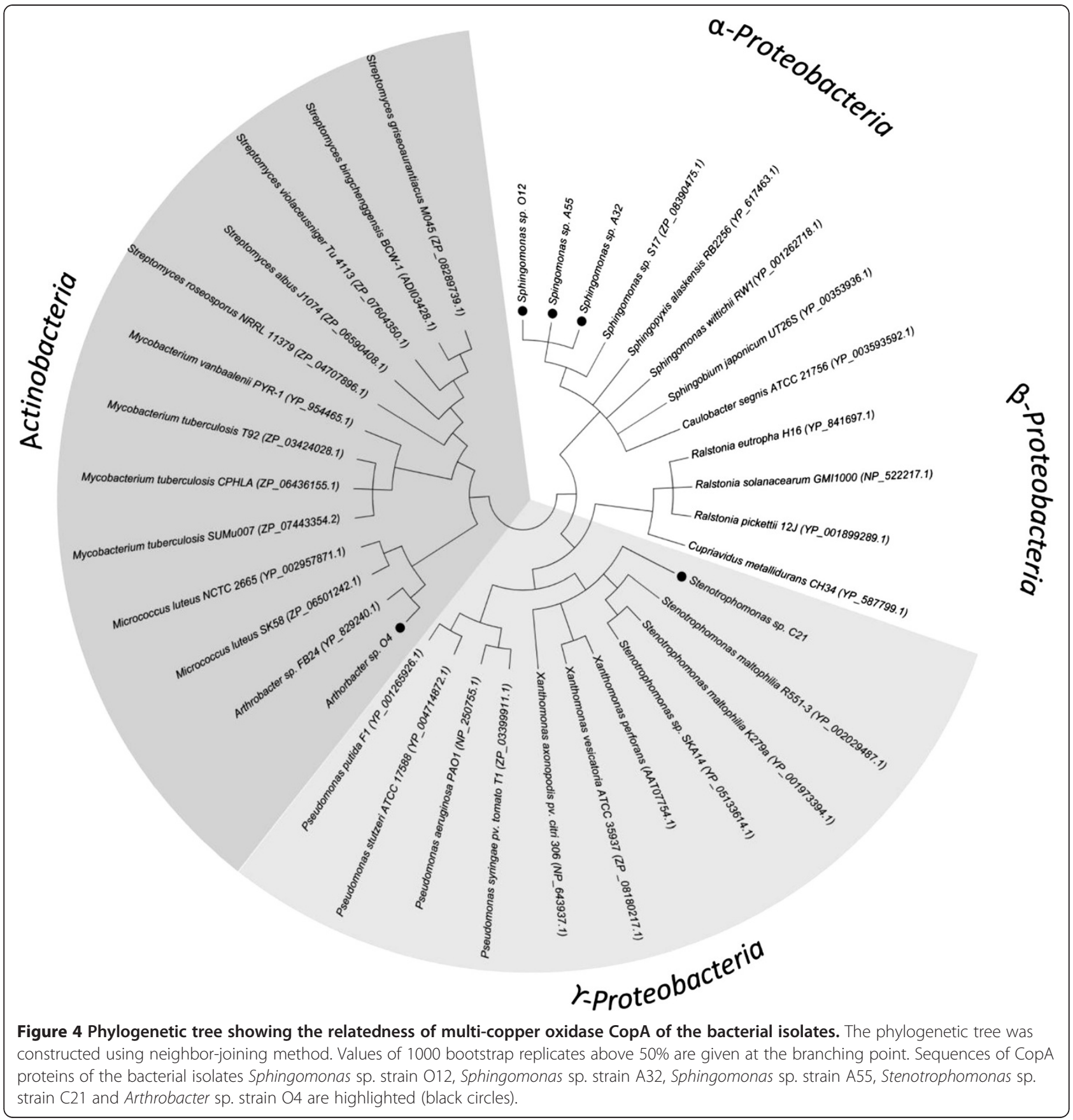

$4.7 \mathrm{mM}), \mathrm{Co}^{2+}(2.5 \mathrm{mM}), \mathrm{Ni}^{2+}(17 \mathrm{mM}), \mathrm{Zn}^{2+}(8.5 \mathrm{mM})$ and $\mathrm{Hg}^{2+}(0.4 \mathrm{mM})$ (Table 2). The MIC of the heavy metal resistant bacterium $C$. metallidurans strain MSR33 to $\mathrm{Cu}^{2+}, \mathrm{Co}^{2+}, \mathrm{Ni}^{2+}, \mathrm{Zn}^{2+}$ and $\mathrm{Hg}^{2+}$ is 3.8, 20, 6.0, 17 and $0.1 \mathrm{mM}$, respectively. Stenotrophomonas sp. strain C21 and Arthrobacter sp. strain O4 showed a high $\mathrm{MIC}$ to $\mathrm{Cu}^{2+}$ (ranged from 3.1 to $3.9 \mathrm{mM}$ ) and $\mathrm{CrO}_{4}^{2-}$ (4.3 mM). C. metallidurans strain MSR33 has a MIC to $\mathrm{CrO}_{4}^{2-}$ of $0.7 \mathrm{mM}$. These high levels of heavy metal resistances may be useful for surviving and adapting to acute heavy metal contamination events in the soil. The mechanisms involved in heavy metal resistance of the strains isolated should be studied. Sphingomonas macrogoltabidus strain $\mathrm{S} 1 \mathrm{n}$ isolated from rhizosphere of Alyssum murale, showed a high $\mathrm{MIC}$ to $\mathrm{Cu}^{2+}(5 \mathrm{mM})$ and $\mathrm{Ni}^{2+}(15 \mathrm{mM})$ [38]. Stenotrophomonas maltophilia strain SM777 isolated from a contaminated culture, showed high $\mathrm{MIC}$ to $\mathrm{Cu}^{2+}(5 \mathrm{mM}), \mathrm{Ni}^{2+}(10 \mathrm{mM}), \mathrm{Zn}^{2+}$ (4 $\mathrm{mM})$, and $\mathrm{Hg}^{2+}(0.05 \mathrm{mM})$ [39]. Arthrobacter sp. strain E9 isolated from a battery-manufacturing contaminated site, showed a high MIC to $\mathrm{Cu}^{2+}(5.8 \mathrm{mM})$, $\mathrm{Co}^{2+}(2.5 \mathrm{mM}), \mathrm{Zn}^{2+}(3 \mathrm{mM})$ and $\mathrm{Hg}^{2+}(0.06 \mathrm{mM})$ [40]. 


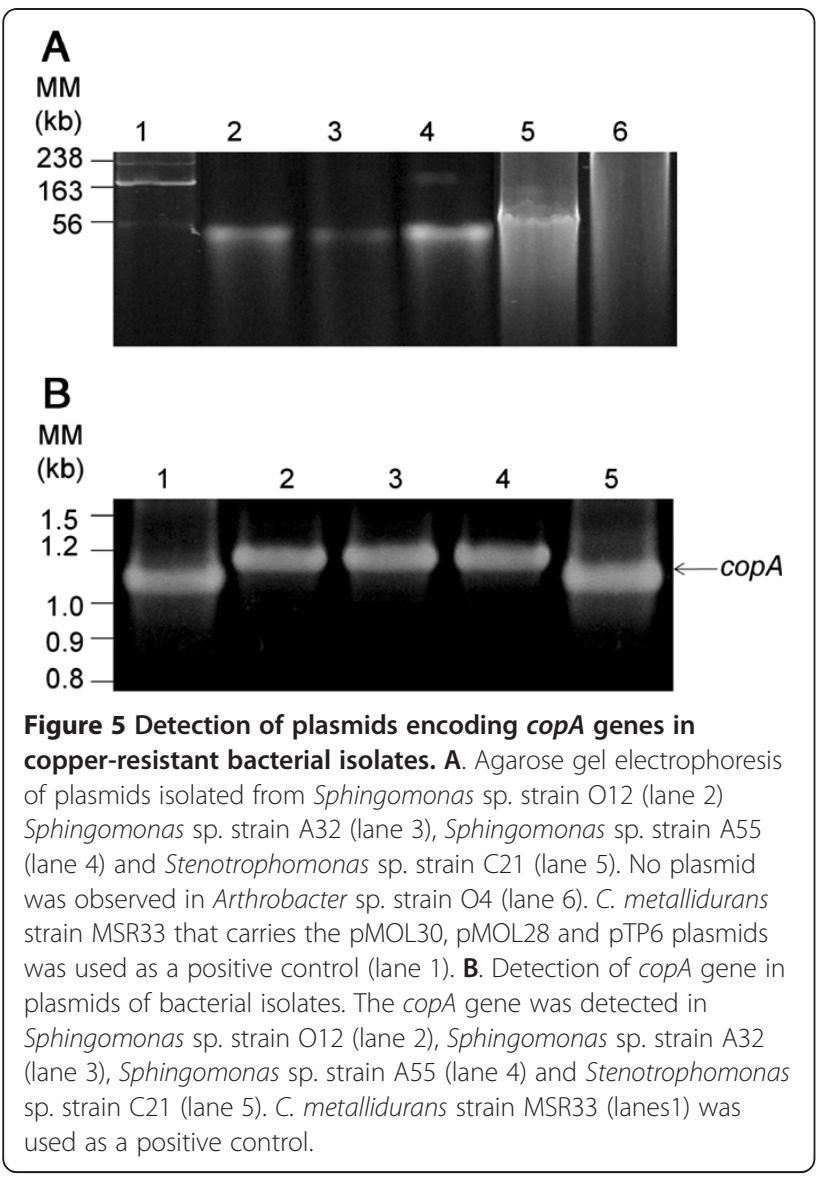

Arthrobacter sp. strain S189 isolated from rhizosphere of Alyssum murale, showed a high $\mathrm{MIC}$ to $\mathrm{Cu}^{2+}$ (10 mM), $\mathrm{Co}^{2+}(5 \mathrm{mM}), \mathrm{Ni}^{2+}(15 \mathrm{mM}), \mathrm{Zn}^{2+}(10 \mathrm{mM})$ and $\mathrm{Hg}^{2+}(0.5 \mathrm{mM})$ [38].

The high level of heavy metal resistance of Sphingomonas sp. strain O12, Sphingomonas sp. strain A32, Sphingomonas sp. strain A55, Stenotrophomonas sp. strain C21 and Arthrobacter sp. strain O4 suggests that these strains possess diverse heavy metal determinants. The use of specific primers based on heavy metal determinants from $C$. metallidurans strain MSR33 did not yield amplicons. In future studies, the presence of heavy metal resistance genes will be studied using more general primers.

In this study, the presence of multi-copper oxidase gene was evaluated in the five isolates using degenerated primers designed for $\operatorname{cop} A$ sequences from Proteobacteria. The presence of multi-copper oxidase $\operatorname{cop} A$ genes in both Gram-negative and Gram-positive bacteria was determined. The presence of $\operatorname{cop} A$ gene in both bacterial groups suggests that the cop system involved in $\mathrm{Cu}$ resistance could be widespread in soil probably through horizontal genes transfer among soil bacteria. The sequence analysis indicates that the CopA proteins from Sphingomonas isolates (O12, A32 and A55),
Stenotrophomonas strain (C21) and Arthrobacter strain (O4) are closely related to CopA from Sphingomonas, Stenotrophomonas and Arthrobacter strains, respectively. The $\operatorname{cop} A$ genes of the fives isolates encode multi-copper oxidases that oxidize $\mathrm{Cu}(\mathrm{I})$ to $\mathrm{Cu}(\mathrm{II})$ but not phenolic compounds or polymers as other multi-copper oxidases reported $[41,42]$.

Phylogenetic analyses of $16 \mathrm{~S}$ rRNA gene sequences indicate that the isolates belong to Sphingomonas, Stenotrophomonas and Arthrobacter genera. The phylogenetic tree obtained from the sequence analysis of $16 \mathrm{~S}$ rRNA gene was similar to those results predicted from the sequence analysis of CopA protein (Figure 3 and 4), showing a high concordance between structural and functional genes.

Mobile genetic elements (MGE) could be involved in the spreading of $\mathrm{Cu}$ resistance determinants, facilitating the adaptation of bacterial communities to copper [43]. Bacteria exposed to copper for a long period of time may acquire MGE such as plasmids carrying copper determinants and, therefore, they become copperresistant bacteria [43-45]. In agreement with this hypothesis, this study showed the presence of the copA gene in metagenomic DNA from the three $\mathrm{Cu}$-polluted soils and the absence of $\operatorname{cop} A$ gene in metagenomic DNA from the non-polluted soil. This study demonstrates that Gram-negative $\mathrm{Cu}$-resistant strains isolated from long-term $\mathrm{Cu}$-contaminated soils carried plasmid with $\mathrm{Cu}$-resistance determinants. The presence of plasmids encoding $\operatorname{cop} A$ genes in Sphingomonas sp. strain O12, Sphingomonas sp. strain A32, Sphingomonas sp. strain A55 and Stenotrophomonas sp. C21 (Figure 5) confirm that MGE are involved in copper resistance in these isolates. The $\operatorname{cop} A(p c o A)$ genes encoding multicopper oxidases have been characterized in plasmids such as pPT23D, pRJ1004 and pMOL30 from Escherichia coli RJ92, Pseudomonas syringae pv. tomato PT23 and Cupriavidus metallidurans $\mathrm{CH} 34$, respectively $[20,21,24]$. The multi-copper oxidase $\operatorname{cop} A$ gene was present in the genome of the Gram-positive bacterium Arthrobacter sp. O4, but plasmids were not detected in this strain. The CopA protein sequence from Arthrobacter sp. O4 possesses a high similarity (68\%) with the multi-copper oxidase gene of Arthrobacter sp. FB24, which is located in a plasmid [46,47]. As plasmid isolation in some bacterial strains is difficult, the presence of the $\operatorname{cop} A$ gene from Arthrobacter sp. O4 in a plasmid could not be excluded.

\section{Conclusions}

This study have shown that the bacterial community diversity of agricultural soil of central Chile analyzed by DGGE was similar in $\mathrm{Cu}$-polluted and non-polluted soils. The $\operatorname{cop} A$ gene encoding multi-copper oxidase was 
detected only in metagenomic DNA of $\mathrm{Cu}$-polluted soils suggesting that $\operatorname{cop} A$ genes are widely spread in contaminated environments. $\mathrm{Cu}$-resistant bacteria were isolated from these long-term polluted soils. The MIC studies on bacterial isolates indicated that $\mathrm{Cu}$-resistant bacteria were also resistant to other heavy metal such as $\mathrm{Ni}^{2+}, \mathrm{Hg}^{2+}$ and $\mathrm{CrO}_{4}^{2-}$. The $\operatorname{cop} A$ gene was detected in the Cu-resistant Sphingomonas, Stenotrophomonas and Arthrobacter strains isolated from the polluted agricultural soils. The multi-copper oxidase $\operatorname{cop} A$ gene is located in plasmids in the four Sphingomonas and Stenotrophomonas strains suggesting that MGEs may spread $\mathrm{Cu}$-resistance determinants in these soils. This study contributes to the understanding of the effect of longterm $\mathrm{Cu}$-pollution on the bacterial community of agricultural soils and to the characterization of novel $\mathrm{Cu}$-resistant bacterial isolates from agricultural soils from the Aconcagua valley.

\section{Competing interests}

The authors have declared that no competing interests exist.

\section{Authors' contributions}

Conceived and designed the experiments: FA, CY, MG, MS. Soil sampling: FA, CY, GB. Performed the experiments: FA, MG, LAR, GB. Analyzed the data: FA, $C Y, G B, M G, L A R, M S$. Contributed reagents/materials/analysis tools: MS, MG, CY. Wrote the paper: FA, LAR, MS. All authors read and approved the final manuscript.

\section{Acknowledgments}

The authors gratefully acknowledge financial support from USM 131109, 13948 and 130836 (MS), FONDECYT 1110992 and 1070507 (MS), FONDECYT 3090071 (CY) and Center of Nanotechnology and Systems Biology (MS, FA). LAR acknowledges a MECESUP FSM0710 postdoctoral fellowship. FA and GB acknowledge CONICYT PhD fellowships.

\section{Author details}

'Laboratorio de Microbiología Molecular y Biotecnología Ambiental, Departamento de Química and Center of Nanotechnology and Systems Biology, Universidad Técnica Federico Santa María, Avenida España 1680, Valparaíso, Chile. ${ }^{2}$ Instituto de Biología, Facultad de Ciencias, Pontificia Universidad Católica de Valparaíso 1680, Valparaíso, Chile.

Received: 20 March 2012 Accepted: 27 August 2012

Published: 5 September 2012

\section{References}

1. Rensing C, Grass G: Escherichia coli mechanisms of copper homeostasis in a changing environment. FEMS Microbiol Rev 2003, 27:197-213.

2. Solioz M, Stoyanov JV: Copper homeostasis in Enterococcus hirae. FEMS Microbiol Rev 2003, 27:183-195.

3. De Gregori I, Fuentes E, Rojas M, Pinochet H, Potin-Gautier M: Monitoring of copper, arsenic and antimony levels in agricultural soils impacted and non-impacted by mining activities, from three regions in Chile. J Environ Monit 2003, 5:287-295.

4. Tembo BD, Sichilongo K, Cernak J: Distribution of copper, lead, cadmium and zinc concentrations in soils around Kabwe town in Zambia. Chemosphere 2006, 63:497-501.

5. Salami IR, Rahmawati S, Sutarto RI, Jaya PM: Accumulation of heavy metals in freshwater fish in cage aquaculture at Cirata reservoir, West Java, Indonesia. Ann N Y Acad Sci 2008, 1140:290-296.

6. Jernström J, Lehto J, Dauvalter VA, Hatakka A, Leskinen A, Paatero J: Heavy metals in bottom sediments of lake Umbozero in Murmansk region, Russia. Environ Monit Assess 2010, 161:93-105.
7. Mudd GM, Patterson J: Continuing pollution from the Rum Jungle U-Cu project: a critical evaluation of environmental monitoring and rehabilitation. Environ Pollut 2010, 158:1252-1260.

8. Hao X, Zhou D, Wang Y, Shi F, Jiang P: Accumulation of Cu, Zn, Pb, and $\mathrm{Cd}$ in edible parts of four commonly grown crops in two contaminated soils. Int J Phytoremediat 2011, 13:289-301.

9. Ranjard L, Echairi A, Nowak V, Lejon D, Nouaim R, Chaussod R: Field and microcosm experiments to evaluate the effects of agricultural $\mathrm{Cu}$ treatment on the density and genetic structure of microbial communities in two different soils. FEMS Microb Ecol 2006, 58:303-315.

10. Giller KE, Witter E, McGrath SP: Toxicity of heavy metals to microorganisms and microbial processes in agricultural soils: a review. Soil Biol Biochem 1998, 30:1389-1414.

11. Wang $Y$, Shi J, Wang H, Lin $Q$, Chen $X$, Chen $Y$ : The influence of soil heavy metals pollution on soil microbial biomass, enzyme activity, and community composition near a copper smelter. Ecotoxicol Environ Saf 2007, 67:75-81.

12. Morgante V, López-López A, Flores C, González M, González B, Vásquez M, Rosselló-Mora R, Seeger M: Bioaugmentation with Pseudomonas sp. strain MHP41 promotes simazine attenuation and bacterial community changes in agricultural soils. FEMS Microbiol Ecol 2010, 71:114-126. Erratum in FEMS Microbiol Ecol 2010, 72:152.

13. Hernández M, Jia Z, Conrad R, Seeger M: Simazine application inhibits nitrification and changes the ammonia-oxidizing bacterial communities in a fertilized agricultural soil. FEMS Microbiol Ecol 2011, 78:511-519.

14. Niklinska M, Chodak M, Laskowski R: Characterization of the forest humus microbial community in a heavy metal polluted area. Soil Biol Biochem 2005, 37:2185-2194

15. Dell'Amico E, Mazzocchi M, Cavalca L, Allievi L, Andreoni V: Assessment of bacterial community structure in a long-term copper-polluted exvineyard soil. Microbiol Res 2008, 163:671-683.

16. Li Z, Xu J, Tang C, Wu J, Muhammad A, Wang H: Application of 16S rRNA PCR amplification and DGGE fingerprinting for detection of shift microbial community diversity in $\mathrm{Cu}-, \mathrm{Zn}$-, and $\mathrm{Cd}$-contaminated paddy soil. Chemosphere 2006, 62:1374-1380.

17. Magnani D, Solioz M: How bacteria handle cooper. In Molecular microbiology of heavy metals. Edited by Nies DH, Silver S. Berlin Heidelberg: Springer-Verlag; 2007:259-285.

18. Wei G, Fan L, Zhu W, Fu Y, Yu J, Tang M: Isolation and characterization of the heavy metal resistant bacteria CCNWRS33-2 isolated from root nodule of Lespedeza cuneata in gold mine tailings in China. $J$ Hazard Mater 2009, 162:50-56.

19. Dupont $\mathrm{CL}$, Grass G, Rensing C: Copper toxicity and the origin of bacterial resistance-new insights and applications. Metallomics 2011, 3:1109-1118.

20. Tetaz TJ, Luke RK: Plasmid-controlled resistance to copper in Escherichia coli. J Bacteriol 1983, 154:1263-1268.

21. Mellano MA, Cooksey DA: Nucleotide sequence and organization of copper resistance genes from Pseudomonas syringae pv. tomato. J Bacteriol 1988, 170:2879-2883.

22. Voloudakis AE, Reignier TM, Cooksey DA: Regulation of resistance to copper in Xanthomonas axonopodis pv. vesicatoria. Appl Environ Microbiol 2005, 71:782-789.

23. Teitzel GM, Geddie A, de Long SK, Kirisits MJ, Whiteley M, Parsek MR: Survival and growth in the presence of elevated copper: transcriptional profiling of copper-stressed Pseudomonas aeruginosa. J Bacterio/ 2006, 188:7242-7256.

24. Monchy S, Benotmane MA, Janssen P, Vallaeys T, Taghavi S, van der Lelie D, Mergeay M: Plasmids pMOL28 and pMOL30 of Cupriavidus metallidurans are specialized in the maximal viable response to heavy metals. J Bacteriol 2007, 189:7417-7425.

25. Nies D: Microbial heavy-metal resistance. Appl Microbiol Biotechnol 1999, $51: 730-750$

26. Lejon DP, Nowak V, Bouko S, Pascault N, Mougel C, Martins JM, Ranjard L: Fingerprinting and diversity of bacterial $\operatorname{cop} A$ genes in response to soil types, soil organic status and copper contamination. FEMS Microb Ecol 2007, 61:424-437.

27. Flores C, Morgante V, González M, Navia R, Seeger M: Adsorption studies of the herbicide simazine in agricultural soils of the Aconcagua valley, central Chile. Chemosphere 2009, 74:1544-1549.

28. Heuer H, Wieland G, Schönfeld J, Schönwälder S, Gomes NCM, Smalla K: Bacterial community profiling using DGGE or TGGE analysis. In 
Environmental Molecular Microbiology: Protocols and Applications. Edited by Rouchelle P. Wymondham: Horizon Scientific Press; 2001:177-190.

29. Hernández M, Villalobos P, Morgante V, González M, Reiff C, Moore E, Seeger M: Isolation and characterization of novel simazine-degrading bacterium from agricultural soils of central Chile, Pseudomonas sp. MHP41. FEMS Microbiol Lett 2008, 286:184-190.

30. Konstatinidis KT, Isaacs N, Fett J, Simpson S, Long DT, Marsh TL: Microbial diversity and resistance to copper in metal-contaminated lake sediment. Microb Ecol 2003, 45:191-202.

31. Rojas LA, Yáñez C, González M, Lobos S, Smalla K, Seeger M: Characterization of the metabolically modified heavy metal-resistant Cupriavidus metallidurans strain MSR33 generated for mercury bioremediation. PLoS One 2011, 14:e17555.

32. Liebert C, Wireman J, Smith T, Summers A: Phylogeny of mercury resistance (mer) operons of Gram-negative bacteria isolated from the fecal flora of primates. Appl Environ Microbiol 1997, 63:1066-1076.

33. Tamura K, Peterson D, Peterson N, Stecher G, Nei M, Kumar S: MEGA5: molecular evolutionary genetics analysis using maximum likelihood, evolutionary distance, and maximum parsimony methods. Mol Biol Evol 2011, 28:2731-2739.

34. Kado C, Liu S: Rapid procedure for detection and isolation of large and small plasmids. J Bacteriol 1981, 145:1365-1373.

35. Guo Z, Meghari M, Beer M, Ming H, Rahman MM, Wu W, Naidu R: Heavy metal impact on bacterial biomass based on DNA analysis and uptake by wild plants in the abandoned copper mine soil. Bioresour Technol 2009, 100:3831-3836.

36. Ellis RJ, Morgan P, Weightman AJ, Fry JC: Cultivation-dependent and -independent approaches for determining bacterial diversity in heavy-metal-contaminated soil. Appl Environ Microbiol 2003, 69:3223-3230.

37. Deng H, Li XF, Cheng WD, Zhu YG: Resistance and resilience of Cu-polluted soil after Cu perturbation, tested by a wide range of soil microbial parameters. FEMS Microbiol Ecol 2009, 70:137-148.

38. Abou-Shanab Rl, van Berkum P, Angle J: Heavy metal resistance and genotypic analysis of metal resistance genes in Gram-positive and Gram-negative bacteria present in Ni-rich serpentine soil and in the rhizosphere of Alyssum murale. Chemosphere 2007, 68:360-367.

39. Pages D, Rose J, Conrod S, Cuine S, Carrier P, Heulin T, Achouak W: Heavy metal tolerance in Stenotrophomonas maltophilia. PLoS One 2008, 3:e1539.

40. Trajanovska S, Britz M, Bhave M: Detection of heavy metal ion resistance genes in Gram-positive and Gram-negative bacteria isolated from a lead-contaminated site. Biodegradation 1997, 8:113-124.

41. Claus H: Laccases and their occurrence in prokaryotes. Arch Microbiol 2003, 179:145-150.

42. Giardina P, Faraco V, Pezzella C, Piscitelli A, Vanhulle S, Sannia G: Laccases: a never-ending story. Cell Mol Life Sci 2010, 67:369-385.

43. Smalla K, Haines AS, Jones K, Krögerrecklenfort E, Heuer H, Schloter M Thomas CM: Increased abundance of IncP-1 $1 \beta$ plasmids and mercury resistance genes in mercury-polluted river sediments: first discovery of IncP-1 $\beta$ plasmids with a complex mer transposon as the sole accessory element. Appl Environ Microbiol 2006, 72:7253-7259.

44. Campbell JIA, Jacobsen CS, Sørensen J: Species variation and plasmid incidence among fluorescent Pseudomonas strains isolated from agricultural and industrial soils. FEMS Microbiol Ecol 1995, 18:51-62

45. de Lipthay JR, Rasmussen LD, Oregaard G, Simonsen K, Bahl MI, Kroer N, Sørensen SJ: Acclimation of subsurface microbial communities to mercury. FEMS Microbiol Ecol 2008, 65:145-155.

46. Jerke $\mathrm{K}$, Nakatsu CH, Beasley F, Konopka A: Comparative analysis of eight Arthrobacter plasmids. Plasmid 2008, 59:73-85.

47. Henne KL, Nakatsu CH, Thompson DK, Konopka AE: High-level chromate resistance in Arthrobacter sp. strain FB24 requires previously uncharacterized accessory genes. BMC Microbiol 2009, 9:199-212.

\section{doi:10.1186/1471-2180-12-193}

Cite this article as: Altimira et al:: Characterization of copper-resistant bacteria and bacterial communities from copper-polluted agricultural soils of central Chile. BMC Microbiology 2012 12:193.

\section{Submit your next manuscript to BioMed Central and take full advantage of:}

- Convenient online submission

- Thorough peer review

- No space constraints or color figure charges

- Immediate publication on acceptance

- Inclusion in PubMed, CAS, Scopus and Google Scholar

- Research which is freely available for redistribution

Submit your manuscript at www.biomedcentral.com/submit
C Biomed Central 